\title{
The Ideal University Teacher according to the Views of Greek Students
}

\author{
Poulcheria Douna ${ }^{1}$, Argyris Kyridis ${ }^{1}$, Christos Zagkos ${ }^{2}$, Zoi Ziontaki ${ }^{1} \&$ Prokopis Pandis $^{2}$ \\ ${ }^{1}$ Aristotle University of Thessaloniki, Greece \\ ${ }^{2}$ Centre for Educational Policy Development (KANEP/GSEE), Greece \\ Correspondence: Christos Zagkos, Centre for Educational Policy Development (KANEP/GSEE), Greece. E-mail: \\ zagbal2003@yahoo.gr
}

Received: March 10, 2015

Accepted: March 26, 2015

Online Published: March 31, 2015

doi:10.5430/ijhe.v4n2p145

URL: http://dx.doi.org/10.5430/ijhe.v4n2p145

\begin{abstract}
During the last decades, there has occurred an increasing interest in the research literature regarding college teaching. Especially the image of the professor is often combined with various stereotypes, prejudiced attitudes and misunderstandings since it is connected with the correlated situation in universities. The current paper is dealing with the image of the ideal professor as expressed by students in universities. The research is conducted with the use of a questionnaire, where students are called to express their agreement or disagreement on certain statements. The data analysis is correlated with various independent variables, such as the students' gender, age and political belief. The statements cover all the aspects of a professor's action, from knowledge and teaching method to political action and relations with society. Hence, we attempt to create a distinct profile of what the students regard as the ideal professor.
\end{abstract}

Keywords: Professor, Profile, Ideal image, Students, Teaching method

\section{Introduction}

During the last decades a plethora of studies has been made regarding issues concerning the tertiary education. Questions about the quality of universities, the evaluation of their faculties or the link between the university studies and the employment are more than frequent in the scientific journals and conferences of several epistemological fields. However, the fundamental question concerning the required skills and characteristics of a university teacher has not been answered yet. Therefore, this is the question that this particular piece of research tried to answer. During our research, 200 randomly chosen university students of the Pedagogical School of the Aristotle University of Thessaloniki were asked to outline the profile of the ideal university teacher.

Outlets as the "Teacher's associations" and "The journal of educational psychology" have created a very fertile ground for a more wide and valid research, regarding the ideal image of the college professor. A lot of researches have been conducted, in order to specify those attitudes and behavioral characteristics that a professor should have, in order to be evaluated as ideal. Nonetheless, it is sensible that it is a complicated procedure, since it is associated with conflicting theoretical orientations, values and issues (Feldman, 1988; Weinberg et al. 2007). One very significant source of data is students, which are the people who have the most "direct access to the professor's wares" (Riley et al. 1950:22). Moreover the validity of the evaluation of university teachers by their students is of great importance, as both research and bibliography have shown (Felder and Brent, 2004; Cashin, 1995; Felder, 1992; McKeachie, 1997; Obenchain et al. 2001). The term "ideal professor" is offered by students who are asked to compare their ideal professors with their typical ones. Hence, students are the ones who can assess in practice their instructors during the pedagogical deed having an overall "glimpse" on the overall behavior of the professors, including the relationship that they tend to develop with their students. Students tend to have a distinct overview of the preferable teaching qualities (Beishline \& Holmes, 1997), as well as the personal characteristic, that refer to the general professor's attitude (Gurung \& Vespia, 2007). On the one hand, there are studies that outweigh the importance of a professor's personal characteristics, such as being empathic, encouraging dialogue and expression of opinion and being truly concerned about students' well-being (Epting, Zinn, Buskist, \& Buskist, 2004; Mclean, 2001). Other studies emphasize the importance of subject mastery, as an indicator of the educator's competency (Arnon \& Reichel, 2007; Roberts, 1981). In addition, there are certain factors that influence the perceptions of students, such as gender and age. Moreover, we should bear in mind that the student's academic experiences, preferences, background and social status play an important role in their perceptions about the ideal teaching (Nimmer and Stone, 1991). Franklin (2001) pointed out some of the main problems concerning the evaluation of teaching data. Besides, according to Bandura (1977) and his social learning theory, individuals tend to 
develop a certain aspect of the world throughout a perpetual process of observation, feedback, novitiate the integration of new ideas and beliefs: "Learning would be exceedingly laborious, not to mention hazardous, if people had to rely solely on the effects of their own actions to inform them what to do. Fortunately, most human behavior is learned observationally through modeling: from observing others one forms an idea of how new behaviors are performed" (p: 122). A very interesting approach of this issue is the one that views professor as the ideal "teacher", which actually combines three vital theoretical elements: scientific, humanistic and traditional dimension of teaching (Kyridis et. al. 2002:78). This aspect of the professor's role is often ignored, since a lot of emphasis is given only to the academic qualities, such as the number of books and papers that a professor has published. The dimension of the "teacher" includes a more ethical aspect of the professor's role, facing him as a mentor, as a person that is there not only to transmit knowledge to the students, but mainly in order to constitute a role model for them. From this aspect, students are both the typical and informal recipients of a professor's abilities, knowledge and wisdom as well as failures and inefficiencies (Monroe and Borzi, 1989). It is the everyday discourse that defines the type of the relationship between the students and the professors (Ibid:79). It is characteristic that Zhivkova (1992) found that students rated their actual professors lower compared to faculty's self-evaluations, something that indicates that the profile of the ideal professor is a complex and multi-dimensional issue.

At this point, we have to mention that the evaluation of university professors by their own students has on the one hand plenty of important advantages, but on the other hand it presents certain limitations as well. For example, the reliability of the evaluations is relatively high, since they are being conducted by students who have attended relevant courses and have freely participated in the evaluation process (Cashin, 1995; Braskamp \& Ory, 1994). On the other hand, several times the methodological tools of the evaluation are not weighted properly, or do not take into account every possible parameter that could influence the results of the evaluation itself (Wright, 1995; Centra, 1993).

\section{The student's ideals}

History has provided as with a lot of ideal and "heroic" professors, such as Plato, Aristotle and Socrates, with characteristics like outrageous ingeniousness and a constant ability to inspire and guide spiritually their students (Knox, 1998:116). Nowadays, higher education has internalized a more practical and technocratic image: "The knowledge of students' concept on the ideal professor is similar to the situation whereby business leaders spend millions of dollars to determine their consumers' perspectives of their product so it can be improved to the satisfaction of their customers. Knowledge of the preferred characteristics of ideal university instructor can play an important role in the process of educational reform and make both teachers and students aware of their responsibilities (Aljubaily, 2010). The above insight views the topic of the ideal professor as a "stock market", where students are the "consumers" and professors are the "product" that has to be modified, according to the consumers' preferences and needs. This example is of course a metaphor, but provides us with the utilitarian ideology that is often dominant in the educational system. A research of the Department of Education in Florina, outlines the concrete image that students have regarding the ideal university teacher. Specifically, one of the most important references regarded the profound knowledge of the subject (30 references, 7,6\%). This knowledge includes not only a specialized training, but a perpetual updating on the scientific developments as well. The students give emphasis on the combination between the universal and specialized knowledge, something that reflects to the overall professor's personality (Kyridis et al. 2002: 84). Another major characteristic is the one regarding the professor's transmissibility, an element that is presented to be as vital as the subject mastery. In addition, 32,2 \% of the students reckon that teaching methodology also plays an important role in the educational procedure (ibid.:84). As far as the professor's attitude and behavior is concerned, students outline the importance of a critical dialogue, where students are allowed to express their own ideas and beliefs, being able to criticize and even question the official knowledge. Hence, the majority of the students tend to challenge the professor's "authority," since they believe that the ideal college teacher "should not regard his/her own ideas and beliefs as the right ones, but he should be open to fresh ideas and perceptions" (ibid. 85). Another important aspect of the student's perceptions is the one regarding the professor's personality. In the research of Hill \& Christian (2012), it is indicated that students prefer professors with personality characteristics such as empathy, compassion and personal interest for their students. Nevertheless, this type of professors may be perceived as "easier graders" or easier to manipulate, owing to the fact that students would expect relaxed standards. From this perspective, the main concern would be that a professor would be regarded as a friend, rather than as a tutor or a mentor. In that case, it is left at the professor's discretion to set the boundaries and maintain his profession prestige. Nonetheless, the evidences are contradictory, since there are other researches that suggest that "Ideal professors are highly accessible to students, allow student input into the course policies and procedures, provide for significant variety in the course, and provide a comfortable learning atmosphere for students" (Epting et al, 2004: 182). In addition, another ambiguous element is that in the above research, students stated that overall, personal characteristics were not important for their Ideal professor. That can be 
explained if we consider that students tend to evaluate teachers as individuals, considering the overall outcome of their teaching method. What is not answered by the above research is whether the ideal professor's profile influences the student's learning, cooperation and performance. Based on the research, we could probably come to the conclusion that the ideal characteristics may not have a linear correlation with the student's performance, but affects indeed the classroom experience. Besides, according to the social cognitive theory, if teachers are more aware of their students' needs, they can make all the necessary alterations and create a higher educational environment. Another important topic is the subject that a professor teaches, as a criterion for the ideal image. According to Santhannam and Hicks (2002), students from physical sciences evaluate their professors as more competent than their counterparts in social sciences. A very interesting approach of the topic from the field of human sciences was held by two researches referring to the ideal law professor (McFarland, 1985; 1986). In the first research, the aim was to indicate certain self-images of American law professors. Three self-images were discovered: the caring liberal art teacher, the teaching lawyer and activist and the tough humanist scholar. The first one "perceives law to be a broad, liberal education (...). The self-persona is one of generalist reaching out to the university community, rather than that of the student-domineering master of the classroom" (McFarland, 1985: 248). In addition, the second type of self-image, the teaching lawyer and activist, is presented from a more practical way of view, indicating the importance of practical experience. Finally, the third type teaches students to think like lawyers, in a rather harsh way, with the assistance of the Socratic Method. The second research of McFarland (1986) investigated the perceptions of law students and practicing lawyers related to the above ideal "Self-personas." As anticipated, student's perceptions were rather different from the professor's self-images. In general, teachers are accustomed to bring to their practice what might be called as personal theories of teaching and learning (T.E.H., 1992; Hofer, 2001; Schon, 1983: 276 - 278). Moreover, a topic that is presented to be ambiguous is that of the ideal professor's background. The majority of subjects stress the importance of the practice specialty and profound experience, whilst they put skills training at the very top of the list. Another topic is the use of the Socratic Method. It is important to notice that this method expresses more the younger students, since they tend to have a more idealized and stereotypical image of the lawyer' work, a belief that declines as the years pass by.

\section{Portrait of the Ideal Professor}

In the study of Epting et al. (2004), certain characteristics appear both in the typical and the ideal professor, such as the clear speech ( $93 \%$ for the ideal and $80 \%$ for the typical) and the daily appearance of the course's goals in the syllabus $(83 \%$ and $52 \%)$. The above characteristics are, however, part of the "technical" educational procedure. As we continue to more substantial features, the distinction becomes more apparent. For example, as far as the students' input in course policies and procedures is concerned, $40 \%$ of the students reckon that this characterizes the ideal professor and only $7 \%$ attribute this attitude to the typical one. Another example is the willingness of the professor to talk informally with students sometimes (43 and $15 \%$ correspondingly). In addition, $78 \%$ of the students believe that the ideal professor lectures, while $93 \%$ attribute this characteristic to the typical professor. Results of a research using diverse sample of undergraduate students enrolled at an urban 4-year university, outline the portrait of the ideal college professor (Strage, 2008). Overall, the most frequently cited characteristics of an "ideal" professor were that they are knowledgeable (46.8\%), caring and concerned about their students (44.2\%) and funny/entertaining (40.2\%). A sizable proportion of respondents also indicated that their professors should be friendly (30.7\%), engaging (27.7\%), enthusiastic (22.7\%), organized (17.6\%). helpful (14.7\%), clear and comprehensible (14.0\%), fair (11.0\%), approachable (10.8\%), accessible $(9.7 \%)$, and challenging $(9.6 \%)$ (Strage, 2008). Also, the most frequently cited characteristics of an "ideal" course were that it be engaging (53.6\%), fun (27.1\%), relevant to students' interests (22.2\%), informative (18.8\%), and in a way that the instructor employs a variety of active learning instructional methods (32.7\%). And while a sizeable number indicated the ideal course be challenging (25.4\%), many specified that it should be easy $(12.8 \%)$ or that the workload should be realistic (10.3\%). As a conclusion, in this study, the ideal professor would be a combination of a "stand-up comic", a serious academician and a mentor, who cares for the students and is ready to guide them. The problematic area here is that each student tends to emphasize on each of this aspects from his/her own point of view.

\section{Purpose of the research}

The main purpose of this research is to examine and identify the students' beliefs and perceptions regarding the ideal image of the college professor. When we use the word "ideal", we subsequently must consider the distinction between the ideal and the typical. In this topic, it may come as a surprise that in the students' mind, a certain lack of this distinction may occur: "We found that preferred qualities and behaviors were not wholly absent in the typical professor - they simply appeared less pronounced than in the Ideal professor (Epting et al, 2004: 182). Nonetheless, in the current survey, these perceptions are not examined in a general framework but in correlation with certain independent variables, such as the students' gender and family background, the educational field of their studies, their 
political beliefs, their general scientific activities and participation in the academic life. These correlations provide the opportunity to create certain patterns of ideals and beliefs, since it is becoming apparent that the students' attitudes towards the ideal professor is thoroughly influenced by factors that are not necessarily and exclusively linked to the educational environment of the university. Moreover, the students' responses are examined in the light of certain sub-categories, in order to create a more systematic and consistent methodological framework.

\section{Methodology}

The research was conducted with the use of a questionnaire, which is regarded to be the most appropriate means in the process of collecting several data from a wide range of people, while it is relatively intelligible as far as the analysis is concerned (Wilson \& McLean, 1994). Also, a questionnaire is anonymous, a fact that is considered to be an advantage, in the effort to achieve the students' honesty and willingness. What is more, the questionnaire is consisted of closed questions, which provide the opportunity for comparisons between the responses, due to certain repeated patterns (Cohen, Manion \& Morrison, 2008). On the other hand, according to Oppenheim (1992), there is the possibility that these closed questions would not thoroughly cover the examined topic. The students' responses are indicated in the form of multiple choice questions of a 5-point Likert scale, according to the level of agreement or disagreement with the given statements. The two edges of the Likert scale are the "I totally disagree" (1) and the "I totally agree (5). The Likert scale was considered to be appropriate, since it provides a variety of responses in the statements (Cohen \& Manion, 2008: 426).

The 200 students who participated in our survey were asked to indicate the degree of agreement or disagreement on a 5 scale Likert type. The various statements are divided into 8 sub-categories:

Table 1. Assurance Index Table

\begin{tabular}{lll}
\hline Scale & Title of the scale & Cronbach's Alpha \\
\hline $1^{\text {st }}$ scale & Teaching method & 0,899 \\
$2^{\text {nd }}$ scale & Knowledge & 0,704 \\
$3^{\text {nd }}$ scale & Relations with students & 0,706 \\
$4^{\text {th }}$ scale & Social personality, relations with the public-social & 0,702 \\
& institutions & 0,701 \\
$5^{\text {th }}$ scale & Personality characteristics & 0,726 \\
$6^{\text {th }}$ scale & Action in the university & 0,768 \\
$7^{\text {th }}$ scale & Ethics & 0,699 \\
$8^{\text {th }}$ scale & Evaluation & 0,816 \\
Overall scale & & \\
\hline
\end{tabular}

A reliability test was conducted, in order to show the Cronbach alpha co-efficiency in the total amount of the 119 statements. Cronbach's alpha is the most common measure of internal consistency ("reliability") and is mainly used in the case of a multiple Likert questions, where it is required to determine whether the scale is reliable. The result is 0,816 , which indicates that the questions that were used are reliable. Since there are 8 sub-categories of the questions-statements, the reliability statistics examine the Cronbach alpha among them as well. It is evident that in each sub-category the Cronbach alpha is 0,7 .

\section{Sample of the research}

Table 2. Demography and social characteristics of the sample

\begin{tabular}{lllll}
\hline Gender & $\mathbf{N}$ & & $\mathbf{\%}$ & \\
\hline Male & 59 & & 29,5 & \\
Female & 141 & & 70,5 & $\mathbf{n}$ \\
Father's occupation & $\mathbf{N}$ & $\mathbf{\%}$ & Mother's occupation & 7 \\
Freelancer-scientist & 39 & 19,5 & Freelancer-scientist & 69 \\
Public official & 60 & 30 & Public official & 19 \\
Private employee & 21 & 10,5 & Private employee & \\
\hline
\end{tabular}




\begin{tabular}{|c|c|c|c|c|}
\hline Freelancer-technician & 14 & 7 & Freelancer-technician & 1 \\
\hline Merchant & 9 & 4,5 & Worker & 13 \\
\hline Worker & 40 & 20 & Farmer & 4 \\
\hline Farmer & 17 & 8,5 & Household & 87 \\
\hline Father's education & $\mathbf{N}$ & $\%$ & Mother's education & $\mathbf{n}$ \\
\hline Primary school & 42 & 21 & Primary school & 18 \\
\hline Secondary school & 71 & 35,5 & Secondary school & 95 \\
\hline \multirow[t]{3}{*}{ Higher education(technical training) } & & & education(technical & 10 \\
\hline & 20 & 29 & University & 59 \\
\hline & & & Master degree & 16 \\
\hline University & 58 & 46,8 & P.H.D degree & 2 \\
\hline \multicolumn{5}{|l|}{ Master degree } \\
\hline & 9 & 4,5 & & \\
\hline & & & Educational level & $\mathbf{n}$ \\
\hline & & & Undergraduate & 197 \\
\hline & & & Postgraduate & 3 \\
\hline & & & Age & $\mathbf{n}$ \\
\hline & & & $18-22$ & 188 \\
\hline & & & 23 and above & 10 \\
\hline & & & Occupation & $\mathbf{n}$ \\
\hline Course attendance & $\mathbf{n}$ & $\%$ & Yes & 50 \\
\hline None & 6 & 3 & No & 149 \\
\hline A little & 68 & 34 & Residence & $\mathbf{n}$ \\
\hline Medium attendance & 41 & 20,5 & Athens-Thessaloniki & 173 \\
\hline Enough & 70 & 35 & Urban Center & 11 \\
\hline Adequate & 15 & 7,5 & Town & 12 \\
\hline $\begin{array}{l}\text { Participation in the academic } \\
\text { activities }\end{array}$ & $\mathbf{n}$ & $\%$ & Rural area & 4 \\
\hline None & 41 & 20,5 & Grade in the secondary school & $\mathbf{n}$ \\
\hline A little & 44 & 22 & Average grade & 36 \\
\hline Medium participation & 65 & 32,5 & Good grade & 66 \\
\hline Enough & 41 & 20,5 & Very good grade & 55 \\
\hline Adequate & 9 & 4,5 & Excellent grade & 10 \\
\hline Scientific field & $\mathbf{n}$ & $\%$ & Political ideology & $\mathbf{n}$ \\
\hline Humanitarian studies & 36 & 18 & Extreme right-wing & 1 \\
\hline Educational science & 100 & 50 & Right-wing & 19 \\
\hline Exact Sciences & 59 & 29,5 & Centre & 145 \\
\hline Social sciences & 5 & 2,5 & Left-wing & 23 \\
\hline Degree of political participation & $\mathbf{n}$ & $\%$ & Extreme left-wing & 7 \\
\hline None & 11 & 5,5 & Anarchist & 5 \\
\hline A little & 98 & 49 & & \\
\hline Indifferent & 25 & 12,5 & & \\
\hline Adequate & 63 & 31,5 & & \\
\hline Extremely & 3 & 1,5 & & \\
\hline
\end{tabular}




\section{Data analysis}

\subsection{The teaching method of the ideal professor}

Table 3. Means table regarding the teaching method of the ideal professor ( $\left(1^{\text {st }}\right.$ subcategory)

\begin{tabular}{lll}
\hline Statement: The ideal professor: & Mean & Std. Deviation \\
\hline A.1 Makes what he/she teaches perfectly understood & 4,24 &, 601 \\
A.2 Is characterized by organization & 4,32 &, 615 \\
A.3 Is flexible & 4,34 &, 562 \\
A.4 Fosters the experiential learning & 4,39 &, 722 \\
A.5 Is ingenious & 4,40 &, 585 \\
A.6 Supports his/her teaching in appropriate means and practices & 4,47 &, 679 \\
A.7 Supports his/her teaching with dialogue & 4,50 &, 593 \\
A.8 Makes use of the new technologies & 4,46 &, 656 \\
A.9 Does not promote the standardized knowledge & 4,44 &, 706 \\
A.10 Takes into account the students' opinions and beliefs & 4,55 &, 591 \\
A.11 Is conciliatory & 4,43 &, 661 \\
A.12 Supports the active participation of students in his lectures & 4,54 &, 641 \\
A.13 Accepts the students' recommendations on how to conduct the lesson & 4,51 &, 687 \\
A.14 Encourages the students' critical thinking & 4,57 &, 572 \\
A.15 Does not limit himself/herself in conventional learning contexts & 4,28 &, 688 \\
A.16 Does not encourage students to research & 2,04 &, 890 \\
\hline
\end{tabular}

The first set of questions regard the teaching method that the ideal professor should have. The students' responses show that most students come in agreement with the given statements, since the majority of them is leaning towards "I agree" and in some cases towards "I totally agree." For instance, the majority seems to totally agree that the ideal professor should support his/her lesson with the appropriate means and practices, but they also give emphasis on the dialogue, as a form of interaction between the professor and the students. They also seem to totally agree that the ideal professor should take into account the students' opinions and beliefs, in order to achieve their active participation. This statement is supported by other studies as well, where students outline the importance of a critical dialogue, where they are allowed to express their own ideas and beliefs, being able to criticize and even question the official knowledge (Kyridis \& Dinas, 2002: 84). Moreover, there is a positive attitude towards statements that emphasize the professor's ability to develop a non-conventional learning framework. In other researches, it is suggested that "Ideal professors are highly accessible to students, allow student input into the course policies and procedures, provide for significant variety in the course, and provide a comfortable learning atmosphere for students" (Epting et al, 2004:182).

\subsection{The knowledge of the ideal professor}

Table 4. Means table regarding the knowledge of the ideal professor $\left(2^{\text {nd }}\right.$ subcategory)

\begin{tabular}{lll}
\hline Statement: The ideal professor: & Mean & Std. Deviation \\
\hline B.1 Has a constant research activity & 4,33 &, 619 \\
B.2 It is necessary to publish his/her researches in conferences & 4,05 &, 890 \\
B.3 Must have made his/her studies in his/her country & 1,81 & 2,301 \\
B.4 Has specialized knowledge of his scientific field & 3,89 & 1,026 \\
B.5 Is not characterized by cognitive unilateralism & 4,30 &, 783 \\
B.6 Is not in obligation to present new auctorial work & 2,28 & 1,130 \\
B.7 Publishes new articles and researches & 3,77 & 1,094 \\
B.8 Is constantly informed on the new developments in his/her area of expertise & 4,46 &, 625 \\
B.9 Is interested in verifying the correctness of his/her knowledge & 4,52 &, 593 \\
B.10 Is not attached to standardized scientific beliefs & 4,46 &, 671 \\
B.11 Has a knowledge of statistics & 3,79 &, 848 \\
B.12 Has the ability to transform theory into practice & 4,33 &, 587 \\
B.13 Supports interdisciplinary & 4,15 &, 613 \\
\hline
\end{tabular}


The second set of questions is referring to the general knowledge, which should be obtained by the ideal professor. Students seem to agree $(51 \%)$ that the ideal professor should constantly participate in research projects, while they totally agree that he/should be interested in the new developments in his/her field of expertise $(50.5 \%)$. Results of a research, using diverse sample of undergraduate students enrolled at an urban 4-year university, outline the portrait of the ideal college professor (Strage, 2008). Overall, the most frequently cited characteristics of an "ideal" professor were that they are knowledgeable (46.8\%). Similar to our findings, in the above research, students who had transferred from community college were more likely to describe their "ideal" professor as organized and fair and their "ideal" course as one that had a more practical, updated dimension, connected to the real world and relevant to their career interests.

7.3 Relations with students of the ideal professor

Table 4. Means table regarding the relations with students of the ideal professor ( $3^{\text {rd }}$ subcategory)

\begin{tabular}{lll}
\hline Statement: The ideal professor: & Mean & Std. Deviation \\
\hline C.1 Should be respectable & 4,37 &, 586 \\
C.2 Should be approachable & 4,46 &, 538 \\
C.3 Should be familiar & 4,42 &, 578 \\
C.4 Should create a learning environment of acceptance & 4,61 &, 538 \\
C.5 Is communicative & 4,63 &, 503 \\
C.6 Understands the modern lifestyle & 4,58 &, 580 \\
C.7 Should be close to students & 4,57 &, 606 \\
C.8 Should socialize with students outside university as well & 4,36 &, 951 \\
C.9 Understands the students' problems and the way of thinking, only if they & 1,89 & 3,686 \\
are young & 4,48 &, 763 \\
C.10 Is willing to cooperate beyond the specified time & 1,60 &, 940 \\
C.11 Should record the students' absences & 2,75 & 1,299 \\
C.12 Does not base his/her evaluation on exams & 4,53 &, 649 \\
C.13 Understands the students' course program and obligations & 4,54 &, 686 \\
C.14 Is not procrastinatory & 4,61 &, 608 \\
C.15 Is consistent & 2,40 & 1,473 \\
C.16 Is meritocratic & 4,63 &, 561 \\
C.17 Does not reproduce relations of inequality & 4,71 &, 509 \\
C.18 Does not act based on personal acquaintances & 4,46 &, 861 \\
C.19 Does not reckon the dynamics of the authoritarian relations & 1,45 &, 800 \\
C.20 Reinforces the ideology of the elite & 3,49 & 1,089 \\
C.21 Treats students as if they were his/her colleagues & & \\
\hline
\end{tabular}

Continuing to the third set of questions, we are dealing with the topic of the relations between the ideal professor and his/her students. The responses show that students imagine the ideal professor as approachable, friendly and respectable. They totally agree that he should be communicative $(64.5 \%)$, close to them $(63 \%)$, showing understanding about their lifestyle (61.5\%). In a similar survey (Kyridis \& Dinas, 2002: 84), the majority of the students tend to challenge the professor's "authority," since they believe that the ideal college teacher "should not regard his/her own ideas and beliefs as the right ones, but he should be open to fresh ideas and perceptions." Nonetheless, in another research, the outcomes showed that older students tend to prefer instructors who are competent rather than those who develop a more personal and open relationship with their students (Hill \& Christian, 2012). This finding is probably associated with the fact that older students are more concerned about their academic orientation. As a result, they tend to choose professors who are in a position to guide them. Other qualities in the third set of questions seem to be meritocracy, consistency and the professor's ability to think and act against the authoritarian relationships. Therefore, $66.5 \%$ of the students reckon that the ideal professor should not reproduce the various social inequalities. 


\subsection{Social personality of the ideal professor}

Table 5. Means table regarding the social personality of the ideal professor $\left(4^{\text {th }} \quad\right.$ subcategory $)$

\begin{tabular}{lll}
\hline Statement: The ideal professor: & Mean & Std. Deviation \\
\hline D.1 Is isolated from the wider public life & 4,27 &, 614 \\
D.2 Collaborates with the public authorities/services & 3,82 &, 748 \\
D.3 Collaborates with the local organizations & 3,78 &, 726 \\
D.4 Is a member of at least one association & 3,50 &, 789 \\
D.5 Participates actively in voluntary programs & 3,58 &, 739 \\
D.6 Does not respond to invitations from the mass media & 3,13 &, 822 \\
D.7 Is unionized & 2,36 &, 982 \\
D.8 Awakens the society & 4,29 &, 637 \\
D.9 Is not politicized & 4,38 &, 854 \\
D.10 Provide solutions to major problems that afflict the society & 4,38 &, 669 \\
D.11 Does not follow neutral conventional solutions & 3,49 & 1,470 \\
D.12 Maintains an open page of on-line communication-cooperation & 4,37 &, 595 \\
D.13 Has a cultural action & 4,17 &, 726 \\
\hline
\end{tabular}

Then, we forward to the fourth set of questions, which regard the ideal professor's social status and relations with the various social and public institutions. The majority of the responses indicate that a professor should co-operate with the public authorities, as well as with the local agencies. Students totally agree with the statement that a professor should not be politically engaged $(56.5 \%)$. Nonetheless, $47.5 \%$ of the students totally agree that the ideal professor is there not only to transmit knowledge, but also to give solutions to major social problems, whilst $37.5 \%$ reckons that he should have the ability to seek for non-conventional options. Moreover, above the half of the respondents (54\%) agree with the statement that the ideal professor should be characterized by a general cultural action.

\subsection{Personality characteristics of the ideal professor}

Table 6. Means table regarding the personality characteristics of the ideal professor ( $5^{\text {th }}$ subcategory)

\begin{tabular}{lll}
\hline Statement: The ideal professor: & Mean & Std. Deviation \\
\hline E.1 Should not foster stereotypic beliefs & 2,39 & 1,417 \\
E.2 Loves modernity & 4,32 &, 623 \\
E.3 Is a critical spirit & 4,45 &, 555 \\
E.4 Is not defined by his/her socio-economic status & 4,52 &, 601 \\
E.5 Is not defined by his/her age & 4,53 &, 567 \\
E.6 Is not defined by his/her gender & 4,51 &, 626 \\
E.7 Is defined by his/her external appearance & 1,50 &, 885 \\
E.8 Has a conservative style of appearance & 1,50 &, 839 \\
E.9 Transmits a positive attitude &, 423 &, 742 \\
E.10 Does not limit his interests only in his scientific field &, 451 &, 650 \\
E.11 Does not reject different beliefs and attitudes &, 460 &, 695 \\
E.12 Is justified to have extreme views & 1,61 &, 989 \\
E.13 Is not ironic & 4,32 &, 872 \\
\hline
\end{tabular}

The fifth category of questions deals with the personal characteristics of the ideal professor. Students reckon that the college professor should prefer modernity and avoid stereotypic ideas. Also, $55.5 \%$ of the respondents totally agree with the opinion that the ideal professors do not identify themselves according to their social and financial status. These responses indicate that students seek for a relatively "modern" image of a professor, something that is also reflected in the statements E10 and E11, where the majority of the respondents totally agree that the ideal professor does not reject different beliefs and is interested in ideas and topics that go beyond his educational area. Also, $52.5 \%$ believes that the right professor transmits a general positive attitude. Strage (2008) is also concluding to similar results as far as the ideal professor's personality. Overall, the most frequently cited characteristics of an "ideal" professor were that they are knowledgeable (46.8\%), caring and concerned about their students (44.2\%) and funny/entertaining $(40.2 \%)$. A considerable proportion of respondents also indicated that their professors should be 
friendly (30.7\%), engaging (27.7\%), enthusiastic (22.7\%), organized (17.6\%). helpful $(14.7 \%)$, clear and comprehensible (14.0\%), fair (11.0\%), approachable (10.8\%), accessible (9.7\%), and challenging $(9.6 \%)$.

\subsection{Action in the university of the ideal professor}

Table 7. Means table regarding the action in the university of the ideal professor $\left(6^{\text {th }}\right.$ subcategory $)$

\begin{tabular}{lll}
\hline Statement: The ideal professor: & Mean & Std. Deviation \\
\hline F.1 Does not socialize with the students' political parties & 3,22 & 1,281 \\
F.2 Keeps a distance from the students' unions & 1,88 & 1,017 \\
F.3 Collaborates constructively with his/her colleagues & 4,40 &, 634 \\
F.4 Does not have a centralized action & 4,06 & 1,127 \\
F.5 Is not interested in topics regarding the administrations of the faculty & 1,72 &, 973 \\
F.6 Cares for the organizations of conferences & 4,09 &, 745 \\
F.7 Motivates the conduction of research programs & 4,25 &, 693 \\
F.8 Fosters the collaboration among universities & 4,43 &, 669 \\
F.9 Promotes the collaboration with universities abroad & 4,55 &, 632 \\
F.10 Demands financial funding & 3,88 &, 916 \\
F.11 Is in favor of free and public textbooks & 4,57 &, 572 \\
F.12 Is against studies from distance & 1,55 & 1,045 \\
F.13 Supports private universities & 1,35 &, 684 \\
F.14 Steps down the connection between the university and the labor market & 3,35 & 1,279
\end{tabular}

In the category that regards the general professor's action in the university, students' responses are relatively contradictory. As stated above, students reckon that a professor should not be politically engaged. Nonetheless, in this set of questions, the $35 \%$ agrees that the ideal professor may transact with the student political parties and the $47.5 \%$ totally disagree with the statement that the ideal professor should be detached from the students' associations. This contradiction might be due to the fact that students sometimes have the "romantic" idea that the general political life is independent from the students' political unions. In any case, they agree that a professor should co-operate with his colleagues, while he should be responsible for organizing conferences and research programs. They also seem to totally agree with the statements F8 and F9, which refer to the co-operation among universities inner and abroad. The vast majority of the students (72.5\%) totally agree with the professor's responsibility to assert funding for education, while the $36 \%$ reckons that he should support the public cost-free textbooks. These responses come in contradiction with the fact that half of them believe that the ideal professor should support the existence of private universities.

\subsection{Ethics of the ideal professor}

Table 8 . Means table regarding the ethics of the ideal professor $\left(7^{\text {th }}\right.$ subcategory)

\begin{tabular}{lll}
\hline Statement: The ideal professor: & Mean & Std. Deviation \\
\hline G.1 Is not based on relations of nepotism & 4,65 &, 701 \\
G.2 is not derived from political circles & 4,60 &, 702 \\
G.3 Is adjacent to the left-wing ideology & 2,27 & 1,055 \\
G.4 Expresses his/her political position & 4,03 & 1,107 \\
G.5 Is not politicized & 4,39 &, 890 \\
G.6 His position is personal & 1,89 & 1,374 \\
G.7 Clearly manifests his/her religious beliefs & 3,79 & 1,070 \\
G.8 Is not trapped in sexual stereotypes & 4,50 &, 695 \\
G.9 Is liberal & 4.67 &, 559 \\
G.10 Is characterized by a moral spirit & 4,69 &, 545 \\
G.11 & 3,80 &, 989 \\
Expresses his/her opinion about topics of nationalism & 3,70 &, 882 \\
G.12 Is a holdover of the traditions & 4,44 &, 677 \\
G.13 Is open to the procedures of his/her re-election & 4,56 &, 616 \\
G.14 Keeps the legal copyrights & 4.34 &, 859 \\
G.15 Rejects "copy-paste" & & \\
\hline
\end{tabular}


The category that seems to be of major interest is the one regarding the ideal professor's ethics. Students seem to agree with statements that emphasize the professor's obligation to avoid all forms of nepotism and political corruption. Hence, most of the students totally agree that the ideal professor should express his/her political beliefs, but not about a specific political party. In general, students' responses are relatively contradictory, since they portrait a professor, who is liberal and independent from sexual stereotypes, but traditional as well. In any case, $73.5 \%$ of them agree with the moral spirit that should characterize the ideal professor.

\subsection{Evaluation of the ideal professor}

Table 9. Means table regarding the evaluation of the ideal professor (8th subcategory)

\begin{tabular}{lll}
\hline H.1 Conducts self-evaluation & 4,72 &, 627 \\
H.2 Supports the evaluation procedures that derive from students & 4,76 &, 642 \\
H.3 Seeks for evaluation derived from colleagues & 3,53 & 1,283 \\
H.4 Does not accept the state's intervention regarding the evaluation process & 2,99 & 1,054 \\
H.5 Is not objective & 1,35 &, 616 \\
H.6 Follows meritocratic processes & 2,46 & 1,207 \\
H.7 Is against the open voting for his/her re-election & 2,12 & 1,048 \\
H.8 Supports the secret elections in the assemblies & 2,17 & 1,055 \\
H.9 Regards as useless the presence of the students' representatives in the & 1,46 &, 838 \\
assemblies & & 1,128 \\
H.10 Supports the publishment of the decisions that were made in the assemblies & 3,93 & 3,99 \\
H.11 Includes the process of the "progress" in the students' evaluation & 4,06 &, 960 \\
H.12 Approves the tactic of the examinations in the end of each semester & 1,59 &, 947 \\
H.13 Is opposed to the revision examinations & 1,42 &, 667 \\
H.14 Is in favor of the system of the "eternal" student & \\
\hline
\end{tabular}

Last but not least, students seem to have a distinct opinion about the ideal professor's evaluation. The vast majority $(78 \%)$, reckons that a self-evaluation is vital, while $77.5 \%$ totally agree with the statement that a professor should support the evaluation deriving from students. Nonetheless, they seem to have a neutral opinion towards the evaluation deriving from other professors. They also seem to emphasize the professor's obligation to be objective, to follow meritocratic processes, to support the open elections and the participation of students' representatives in the general assemblies. As far as the students' evaluation is concerned, the respondents show a positive attitude towards the statements $\mathrm{H} 11$ and $\mathrm{H} 12$ that refer to the necessity of the final examinations. Regarding the independent variable gender, correlations were observed with a degree of significance to the following dependent variables: B2( $\mathrm{F}=4,488$, $\operatorname{sig}=0,035), \mathrm{D} 10(\mathrm{~F}=6,165, \mathrm{sig}=0,014)$ and $\mathrm{D} 11(\mathrm{~F}=12,1912$, sig=0). Specifically, in the statement $\mathrm{B} 2$, the majority of male students seem to agree with the professor's obligation to publish his researches in conferences. In addition, statements D10 and D11 refer to the professor's ability to solve the various social problems and search for non-conventional solutions. As a matter of fact, men agree with these statements with greater frequency compared to women.

Correlations of great significance were observed in the first set of questions that refer to the professor's teaching methodology. For instance, in the statement $\mathrm{A} 1(\mathrm{~F}=3,253$, sig=0,041), younger students, aged 18-23, seem to give greater emphasis on the professor's ability to teach in a comprehensible way. Also, in statement $\mathrm{A} 5(\mathrm{~F}=3,696$, sig= $0,027)$, half of the younger students agree with the statement that the ideal professor should be inventive. We should also mention statements $\mathrm{A} 6(\mathrm{~F}=4,185$, sig=0,017), $\mathrm{A} 8(\mathrm{~F}=4,295$, sig=0,015), $\mathrm{A} 15(\mathrm{~F}=5,479$, sig=0,005), $\mathrm{C} 1(\mathrm{~F}=6.415$, sig $=0,002), \mathrm{C} 16(\mathrm{~F}=11,542, \mathrm{sig}=0)$. In statements $\mathrm{A} 6$ and $\mathrm{A} 8$, the majority of younger students seem to totally agree with the ideal professor's ability to use the appropriate educational means and practices, as well as the new technologies. In statement A15, younger students agree with the opinion that the ideal professor should act in a non-conventional educational framework, while half of them agree with the statement $\mathrm{C} 1$, which describes the ideal professor as someone respectable. Nonetheless, in statement C16, older students agree with greater frequency with the opinion that the ideal professor should be meritocratic.

Profiles described by younger students, and by students matriculating straight from high school, appear to have a repeated pattern in literature (Epting et al; Feldman, 1988; Carlan, 2001). In the studies mentioned above, age played a significant role, since older students described their ideal professor as organized and flexible, while they also 
presented the ideal class as an organized one. In addition, another important point is that students, who were derived straight from high school, differed a lot from those that matriculated from community college. On the contrary, the average-aged students used adjectives, like "funny" and "enthusiastic", when referring to the ideal professor and they frequently described their ideal course as fun, interactive and engaging. Nevertheless, students who had transferred from community college were more likely to describe their "ideal" professor as organized and fair and their "ideal" course as one that had a more practical, updated dimension, connected to the real world and relevant to their career interests. Nonetheless, in another research, the outcomes showed that older students tend to prefer instructors who are competent rather than those who develop a more personal and open relationship with their students (Hill \& Christian, 2012). This finding is probably associated with the fact that older students are more concerned about their academic orientation. As a result, they tend to choose professors who are in position to guide them. Besides, older students are usually paying for their education, whereas younger students depend on their parents, so they have a more "carefree" perspective on knowledge. In addition, older students are more likely to process what is described in bibliography as "a locus of control", referring to people who view themselves as responsible of the outcome of events in their lives (Martin \& Dixon, 1994; Nunn, 1988; Rotter, 1966). In that case, older students have certain life experiences that their younger counterparts have not obtained yet. Also, it should be noted that there was found no remarkable difference between graduate and undergraduate students, a fact that is more or less evidence in our study as well,

Moreover, in the variable father's occupation, correlations of great significance were detected in statements $\mathrm{B} 1(\mathrm{~F}=2,202$, sig=0,044), $\mathrm{B} 2(\mathrm{~F}=2,838$, sig=0,011), $\mathrm{B} 3(\mathrm{~F}=4,111, \mathrm{sig}=0,001), \mathrm{C} 8(\mathrm{~F}=3,660, \mathrm{sig}=0,002), \mathrm{C} 11(\mathrm{~F}=3,279$, sig $=0,004)$. Specifically, students, whose fathers are occupied as farmers reward with greater frequency the constant scientific research, a result that may come as a surprise. Also, in statement B2, students whose fathers are public officials, seem to give more emphasis in the professor's requirement to publish his scientific results in various conferences. Also, in statement $\mathrm{C} 14(\mathrm{~F}=3,775$, sig=0,001),students, whose fathers are farmers, seem to lean more towards the positive axis, regarding the professor's ability to avoid procrastination. Moreover, mother's occupation also seems to play a significant role, in statements $\mathrm{A} 2(\mathrm{~F}=2,682$, sig $=0,016), \mathrm{A} 4(\mathrm{~F}=3,974, \mathrm{sig}=0,001), \mathrm{A} 8(\mathrm{~F}=5,260$, $\mathrm{sig}=0), \mathrm{A} 11(\mathrm{~F}=4,655, \mathrm{sig}=0), \mathrm{A} 15(\mathrm{~F}=3,655, \mathrm{sig}=0,002), \mathrm{C} 13(\mathrm{~F}=3,267, \mathrm{sig}=0,004), \mathrm{C} 14(\mathrm{~F}=3,775), \operatorname{sig}=0,001)$. Specifically, students, whose mothers are occupied as farmers, give greater emphasis on the professor's methodology, while they reward more the experiential teaching methods, something that is probably connected with the nature of this specific occupation, which has a more practical dimension. In statements A8, students, whose mothers are occupied as public officials, acknowledge the usage of new technological means, while in statement A9, they stress that the ideal professor should avoid standardized knowledge.

As far as the variable "mother's education" is concerned, significant correlations were observed in statements $\mathrm{A} 4(\mathrm{~F}=3,098$, sig=0,010), $\mathrm{C} 14(\mathrm{~F}=3,562, \mathrm{sig}=0,004), \mathrm{C} 18(\mathrm{~F}=3,502, \mathrm{sig}=0,005), \mathrm{D} 9(\mathrm{~F}=3,905, \mathrm{sig}=0,002), \mathrm{F} 3(\mathrm{~F}=3,460$, $\mathrm{sig}=0,005)$. A general assumption that could be made is that students, whose parents have graduated from university, tend to give greater emphasis on certain characteristics, such as political independency, integrity and co-operation.

Forwarding to the independent variable "lessons attendance", significant correlations were mainly observed in the last set of questions, which regard the professor's attitude towards evaluation. For instance, we should mention statements $\mathrm{H} 6(\mathrm{~F}=3,956$, sig=0,004), $\mathrm{H} 9(\mathrm{~F}=3,518$, sig=0,008), $\mathrm{H} 13(\mathrm{~F}=4,054$, sig=0,004). In statement $\mathrm{H} 6$, it is observed that students, who attend lessons frequently, tend to reward the professor's meritocracy with greater frequency.

Correlations of great significance were also observed among students who work and those who do not have an occupation. For instance, in statements $\mathrm{A} 10(\mathrm{~F}=3,181$, sig $=0,044)$ and $\mathrm{A} 11(\mathrm{~F}=5,285$, sig $=0,006)$, students who do not work reward more the professor's ability to accept and respect the students' opinion. Also, correlations were observed in statements $\mathrm{G} 7(\mathrm{~F}=8,398$, sig=0), $\mathrm{G} 11(\mathrm{~F}=3,290$, sig=0,039), G15(F=3,55, sig=0,037), H1( $\mathrm{F}=3,534$, $\mathrm{sig}=0,031), \mathrm{H6}(\mathrm{F}=3,685$, sig $=0,027)$.

Another important factor seems to be the students' participation in the various activities of the campus. Correlations of significance were observed in statements $\mathrm{B} 7(\mathrm{~F}=4,858$, sig=0,001), $\mathrm{C} 11(\mathrm{~F}=4,764$, sig=0,001), $\mathrm{E} 7(\mathrm{~F}=3,402$, sig=0,010), $\mathrm{E} 8(\mathrm{~F}=3,479$, sig=0,009), $\mathrm{E} 12(\mathrm{~F}=6,496$, sig=0), $\mathrm{F} 2(\mathrm{~F}=5,211$, sig=0,001), $\mathrm{F} 5(\mathrm{~F}=3,502, \operatorname{sig}=0,009)$, $\mathrm{Z} 5(\mathrm{~F}=3,431$, sig=0,010), $\mathrm{Z7}(\mathrm{F}=4,205$, sig=0,003). A general statement that could be made, based on the statistically significant data, is that those who participate actively in the university life tend to give greater emphasis on the ideal professor's ability to organize research programs and participate in the administration of the faculty. Also, more active students reward the professor's positive attitude and his general ability to extend his activity in topics beyond his/her area of expertise. 
A significant variable seems to be the students' political ideology, as observed in the statements $\mathrm{C} 8(\mathrm{~F}=3,725$, sig=0,003), $\mathrm{C} 10(\mathrm{~F}=4,434, \quad$ sig $=0,001), \quad \mathrm{C} 14(\mathrm{~F}=7,717, \quad \operatorname{sig}=0), \quad \mathrm{C} 20(\mathrm{~F}=7,655, \quad$ sig $=0), \quad \mathrm{D} 7(\mathrm{~F}=3,142, \quad$ sig $=0,009)$, $\mathrm{D} 9(\mathrm{~F}=6,717$, sig=0), $\mathrm{D} 10(\mathrm{~F}=3,196$, sig=0,009), $\mathrm{D} 11(\mathrm{~F}=3,553$, sig=0,004). In general, students with more left-wing beliefs tend to reward more attitudes, such as the professor's ability to seek for non-conventional ways and solutions (D11), to get rid of sexual stereotypes (G8) as well as to care for the major problems of society (D10).

\section{Conclusion}

Examining the above results, we should bear in mind that the various variables, such as the students' age, gender and political beliefs play a vital role in the way that each students perceives the ideal image of the college professor. On the one hand, there are certain features that were indeed chosen with great frequency, such as the wise and knowledgeable professor, yet friendly, approachable and familiar to the average student (Wagenaar, 1995). On the other hand, certain ambiguous responses have been detected, mainly regarding the professor's role, outside the area of university. There are statements, where students tend to agree that the ideal professor should intervene in issues that are not exclusively in his/her scientific area. Nonetheless, there are some controversial responses, mainly regarding the professor's attitude towards the students' political parties and the general political life of the campus. As far as the method of teaching is concerned, students seem to reckon that the ideal professor should make use of the various practices and technological means, but they also give great value to his ability to talk with students, to take their opinion into account, to regard them as an integral part of the learning procedure. They also agree with statements that emphasize critical thinking, non-conventional practices and innovative activities. Moreover, they reward the general research activity and the students' participation in the various research programs. The same pattern follows the second set of questions, where students think that the ideal professor should have a full knowledge of his/her educational field, but they also emphasize the ability to transform theory into practice and to give a more tangible dimension in the learning procedure. Hence, they agree with statements that stress the professor's ability to publish new articles and publications and to search for new knowledge, whilst not being attached to standardized scientific beliefs (Seldin, 1993).

Students also seem to imagine a professor that is close to them, that is friendly and intimate, trustworthy and eager to understand their way of thinking and living. As Giroux (1988) states, the educational process is considered to be a social process. Therefore, professors are required to show sensitivity and discretion towards the financial and social background of each student (Giroux, 1988). They generally appreciate an honest communication, where the professor creates a friendly, "cozy" atmosphere. The majority of them also believe that the ideal professor should be in constant interaction with the public life, in order to have a cultural and political action and to use his/her power, in order to change society. These responses could be combined with what Aronowitz and Giroux defined as the role of the intellectual reformer, who uses the pedagogical act in order to direct the political sphere: "That is intellectuals, who are part of a specific class, group or movement and who serve to give it coherence and awareness of its own function in the economic, social and political fields (Aronowitz \& Giroux, 1993: 155). The term was originally used by Gramsci (1971), who analyzed the social function of intellectuals around the following categories of teachers: the reformers intellectuals, the critical intellectuals, the ensconced intellectuals and the hegemonic intellectuals. As he states, "the mode of being of the new intellectual can no longer consist in eloquence ... but in active participation in practical life, as constructor, organizer, "permanent persuader" and not just a simple orator..." (Gramsci, 1971:10). In this context, we are interested in the reformers intellectuals, because they are the ones that lay the foundation for a critical pedagogy, perceiving education as a continuous struggle for what is perceived as legal and what is seen as marginalized knowledge. As far as the ideal professor's personality is concerned, students give emphasis on characteristics, such as integrity, morality, meritocracy and liberality. However, according to students, this liberality does not mean that a professor should not follow the legal processes, as conducted in the assemblies and the various elections. They mainly imagine a professor who is not afraid to be subjected to criticism and evaluation by the students and the colleagues. A professor who expresses his/her political beliefs, but is not a mouthpiece of the various political parties. Last but not least, students appreciate a professor who is objective and base the students' evaluation not exclusively on the final exams, but on other practices as well (Patrick and Smart, 1998).

\section{References}

Aljubaily, H.Y. (2010). Measuring university students' perceptions of characteristics of ideal university instructor in Saudi Arabia and the United States: An application of nonparametriitem response theory study. A Dissertation Submitted in Partial Fulfillment of the Requirements for the Degree of Doctor of Philosophy, University of northern Colorado, Greeley, Colorado. 
Arnon, S., Reichel, N. (2007). "Who is the ideal teacher? Am I? Similarity and differences in perception of students of education regarding the qualities of a good teacher and of their own qualities as teachers". Teachers and Teaching: theory and practice, 13 (5), 441-464. http://dx.doi.org/10.1080/13540600701561653

Aronowitz, S., \& Giroux, H. A. (1993). Education still under siege. Westport, Conn: Bergin \& Garvey.

Bandura, A. (1977). Social Learning Theory. New York: General Learning Press

Beishline, M. J., \& Holmes, C. B. (1997). Students preferences for various teaching styles. Journal of instruction Psychology, 24, 95-99

Braskamp, L. A. \& Ory, J. C. (1994). Assessing faculty work: Enhancing individual and institutional performance. San Francisco: Jossey-Bass.

Carlan, P. (2001). Adult students and community college beginnings: Examining the efficacy of performance stereotypes on a university campus. College Student Journal, 35(2), 169-181.

Cashin, W. E. (1995). Student Ratings of Teaching: The Research Revisited. IDEA Paper No. 32, IDEA Center, Kansas State University.

Cashin, W.E. (1995). Student Ratings of Teaching: The Research Revisited. IDEA Paper No. 32, Kansas State University Center for Faculty Evaluation and Development, www.idea.ksu.edu, September.

Centra, J. A. (1993). Reflective faculty evaluation. San Francisco: Jossey - Bass.

Cohen, L., Manion, L., Morrison, K.. (2000). Methodology of educational research, Athens: Metaixmio. http://dx.doi.org/10.4324/9780203224342

Epting, L. K., Zinn, T. E., Buskist, C. \& Buskist, W. (2004). Students perspectives on the distinction between ideal and typical teachers. Teaching of Psychology, 31 (3), 181-183. http://dx.doi.org/10.1207/s15328023top3103_5

Felder, R.M., \& Brent, R. (2004). How to evaluate teaching. Chem. Engr. Education, 38(3), 200-202.

Felder, R.M. (1992). What Do They Know, Anyway? Chemical Engineering Education, 26(3), 134 - 135. http://www.ncsu.edu/felder-public/Columns/Eval.html

Feldman, K. (1988). Effective college teaching from the students' and faculty's view: Matched or mismatched priorities?, Research in Higher Education, 28(4), 291-344. http://dx.doi.org/10.1007/BF01006402

Franklin, J. (2001). Interpreting the numbers: Using a narrative to help others read student evaluations of your teaching accurately. New Directions for Teaching and Learning, 87, 85-100. http://dx.doi.org/10.1002/tl.10001

Giroux, H., A. (1988). Schooling and the struggle for public life: critical pedagogy in the modern age, Minneapolis: University of Minnesota Press.

Gramsci, A. (1971). Selections from the Prison Notebooks. London: Lawrence and Wishart.

Gurung, R. A. R. \& Vespia, K. M. (2007). Looking good, teaching well? Linking liking, looks, and learning. Teaching of Psychology, 34, 5-10.

Hill, J., S. \& Christian, T. Y. (2012). College Student Perceptions and Ideals of Teaching: An Exploratory Pilot Study. College Student Journal, 46(3), 589-602.

Hofer, B. (2001). Personal epistemology research: Implications for learning and instruction. Educational Psychology Review, 13(4), 353-382. http://dx.doi.org/10.1023/A:1011965830686

Knox, D. K. (1998). Socrates: the first professor. Innovative Higher Education, 23(2), 115-126. http://dx.doi.org/10.1023/A:1022900208893

Kyridis A., Dinas, K., Ioannitou, E., Lambropoulou, V. \& Vlachaiti, V. (2002). University students describe the ideal university professor. Contemporary Education, 122, 78-87.

Martin, N. \& Dixon, P. (1994). The effects of freshman orientation and locus of control on adjustment to college: A follow-up study. Social behavior and personality, 22(2), 201-208. http://dx.doi.org/10.2224/sbp.1994.22.2.201

McLean, M. (2001). Qualities attributed to an ideal educator by medical students: should faculty take cognizance? Medical Teacher, 23, (4), 367-370. http://dx.doi.org/10.1080/01421590120057030

Mc Farland, D., D. (1985). Self-Images of Law Professors: Rethinking the Schism in Legal Education. Journal of Legal Education, Vol. 232. 
Mc Farland, D. D. (1986). Students and Practicing Lawyers Identify the Ideal Law Professor. Journal of Legal education, 36.

McKeachie, W.J. (1997). Student Ratings: The Validity of Use. American Psychologist, 52(11), 1218 - 1225. http://dx.doi.org/10.1037/0003-066X.52.11.1218

Monroe, C., \& Borzi, M. G. (1989). Methodological issues regarding student evaluation of teachers: A pilot study. ACA Bulletin, 70, 73-89.

Nimmer, J.G., \& Stone, E. F. (1991). Effects of grading practices and time of rating on student ratings of faculty performance and student learning. Research in Higher Education, 32, 195-215. http://dx.doi.org/10.1007/BF00974437

Nunn, G. D. (1988). The relationship between children's locus of control and perceptions of home, school, and peers. Journal of Human Behavior and Learning, 5, 18-21.

Obenchain, K. M., Abernathy, T. V., \& Wiest, L. R. (2001). The reliability of students' ratings of faculty teaching effectiveness. College Teaching, 49(3), 100 - 104. http://dx.doi.org/10.1080/87567550109595859

Oppenheim, A. (1992). Questionnaire Design, Interviewing and Attitude Measurement, London: Pinter.

Patrick, J., \& Smart, R. M. (1998). An empirical evaluation of teacher effectiveness: The emergence of three critical factors. Assessment and Evaluation in Higher Education, 23(2), 165-178. http://dx.doi.org/10.1080/0260293980230205

Riley, J., Bryce, F., R. \& Lifshitz, M. (1950). The student Looks at his Teacher. New Brunswick, N.J.: Rutgers University Press.

Roberts, D. C. (1981). Student leadership programs in higher education. Washington, DC: American College Personnel Association.

Rotter, J. B. (1966). Generalized expectancies of internal versus external control of reinforcements. Psychological Monographs , 80 (609). http://dx.doi.org/10.1037/h0092976

Santhanam, E., \& Hicks, O. (2002). Disciplinary, gender and course year influences on student perceptions of teaching: Explorations and implications. Teaching in Higher Education, 7, 17-31. http://dx.doi.org/10.1080/13562510120100364

Schon, D. (1983). The reflective practitioner: How professionals think in action. New York: Basic Books.

Seldin, P. (1993). The use and abuse of student ratings of professors. Chronicle of Higher Education, 39(46), p. A40.

Strage, A. 2008). Traditional and non-traditional college students' descriptions of the "ideal" professor and the "ideal" course and perceived strengths and limitations. College student Journal, 42(1), 225-231.

Teaching Evaluation Handbook, (1992). Cornell University. Ithaca: New York. http://www.cte.cornell.edu/documents/Teaching\%20Evaluation\%20Handbook.pdf

Wagenaar, T. C. (1995). Student evaluation of teaching: Some cautions and suggestions. Teaching Sociology, 23(1), 64-68. http://dx.doi.org/10.2307/1319382

Weinberg, B. A., Fleisher, B. M., \& Hashimoto, M. (2007). Evaluating methods for evaluating instruction: The case of higher education. National Bureau of Economic Research working paper 12844: Cambridge, MA. http://dx.doi.org/10.3386/w12844

Wilson, N \& McClean, S. (1994). Questionnaire Design: A. Practical Introduction. University of Ulster.

Wright, W. (Ed) (1995). Teaching Improvement Practices. Bolton, MA: Anker Publishing Co.

Zhivkova, H. (1992). Evaluation of the lecturer: The ideal and reality. Annals of Community-Oriented Education, 5, 215-222. 